 \\ Brasileira \\ de Enfermagem \\ REBEn}

\section{Nursing informatics: learning from the past to build a new future}

\author{
Informática em Enfermagem: aprendendo com o passado para construir um novo \\ futuro \\ Informatica em Enfermería: aprendendo con el pasado para construyr un nuevo \\ futuro
}

Heimar F. Marin

RN, MS, PhD, FACMI . Professor at Federal University of São Paulo. heimar@denf.epm.br

Eduardo Marques

Médico. Doutor em Informática Médica, Professor da UERJ. Diretor Administrativo da Clínica São Vicente, $R J$.

Adress for Correspondence: Rua Napoleão de Barros 754 04024-002 - São Paulo - SP.

\section{ABSTRACT} Informatics Association (IMIA) conferences. Descriptores: Medical informatics; Education; History, nursing.

\section{RESUMO}

Health care and health information have been around since the time of Hippocrates or even before. Through the historical evolution, it is observed that the knowledge and information that were simple and easy to learn and retain by that time, became much more complex. This paper presents a brief reviewing on the evolution of nursing informatics and how it grew up and made itself visible during all these years of International Medical

A assistência à saúde e a informação em saúde são discutidas desde o tempo de Hipócrates ou até antes disto. Através da evolução histórica, é observado que o conhecimento e a informação que eram simples e fáceis de se aprender e reter naquele tempo, tornaram-se muito mais complexas. Este artigo apresenta uma breve revisão da evolução da Informática em Enfermagem e como a mesma cresceu e se fez visível ao longo destes anos nos congressos da Associação Internacional de Informática Médica (IMIA) .

Descritores: Informática médica; Educação; História da enfermagem.

\section{RESUMEN}

La atención a la salud y la información en salud han sido discutidas desde el tiempo de Hiprocates o hasta antes de esto. Través de la evolución historica, es observado que el conocimiento y la información que eran simples y faciles de se aprender y retener en esto tiempo, tornaranse mucho más complejos. Esto artículo presenta una breve revisión sobre la evolución de la Informática en Enfermería y como la misma se ha tornado grande y visible durante los años en los congressos de la Associación Internacional de Informática Medica (IMIA). Descriptors: informática Medica; Enseñanza; Historia de la enfermería.

Marin HF, Marques E. Nursing Informatics: learning from the past to build a new future. Rev Bras Enferm 2005 mar-abr; 58(2):143-6.

I love and admire the past, but I would like the future to be even better

\section{Romain Rolland}

Knowing from the past, learning from the experience of pioneers and professionals that built the nursing informatics (NI) field help us to build the foundation of our future in a more resistant and solid manner. Reflecting on the evolution of the field gives the opportunity to look abroad and consider the values of several cultures and analyze how nursing informatics was built in different countries, different continents.

\section{A new field of knowledge was born - 1974 is the year!}

Health care and health information have been around since the time of Hippocrates or even before. Through the historical evolution, it is observed that the knowledge and information that were simple and easy to learn and retain by that time, became much more complex. By 1974, technology was being used in several areas and the amount of available information was provoking a genuine revolution. To be updated could represent a challenge and compromise the quality of care.

In healthcare, some visionary people start to coordinate developments, establishing a network where resources and findings could be shared among professionals, organizations, regions and countries. The International Medical Informatics Association - IMIA was being engendered!

The first IMIA President was Professor François Grémy. He was founder and president from 1968 to 1975. During his term the first global conference on Medical Informatics took place: MEDINFO 
was created to serve as a forum where people could be integrated and share their experiences. Today, after 30 years since the first one, the 11th MEDINFO has representatives from 43 countries and we are covering the six continents.

Since its creation MEDINFO is being organized every three years. Countries that host the conference were: Sweden (Stockholm, 1974), Canadá (Toronto, 1977), Japan (Tokyo, 1980), The Netherlands (Amsterdam, 1983), United States (Washington, 1986), Singapore (Singapore, 1989), Switzerland (Geneva, 1992), Canadá (Vancouver, 1995), Korea (Seoul, 1998), England (London, 2001), United States (San Franscisco, 2004). The next conference will be held in 2007 in Brisbane, Australia. Nurses will lead the conference. The president of Organizinz Committee is Dr. Evelyn Hovenga (Australia); the Scientific Committee is co-chaired by Alexa McGray (USA) and Heimar F. Marin (Brazil).

In 1974, at the first MEDINFO conference among 177 papers five of them were in nursing informatics ${ }^{(1)}$.

In 1992, in Geneva, Switzerland the scientific program comprised 259 oral presentations and 20 were in NI. This meeting was a remarkable conference: the scientific quality was impressive and the number of countries that participated was higher than usual(2). A first paper in nursing informatics from Brazil was presented. This was important because up to that date, countries representatives were from Europe, Asia and North America.

In 1995, other important fact to highlight is a paper in nursing informatics from South Africa that was firstly included on the scientific program ${ }^{(3)}$. Consequently, from seven continents (Africa, Antarctica, Asia, Australia, Europe, North America and South America), six were presented!

In 1998, Seoul, nursing informatics was integrated in the program over a variety of sessions and starts to determine a tendency integration ${ }^{(4)}$. Nurses participated in different sessions other then those ones dedicated to nursing informatics field and the main topics related to nursing activities in health or nursing informatics were: internet applications, evidence and outcomes, nursing documentation, education and terminology.

Since the 1998 conference, following trends and tendencies, NI is deeply integrated and nurses are demonstrating their contributions to this field of healthcare informatics. In addition, there are also included sessions dedicated to present specific concerns and discuss future directions of the field. It is clear that nurses want to tell to the whole audience how important contributions we have done to enhance health informatics around the world.

Looking back to all previous MEDINFO conferences, we saw that nurses participated since the very beginning. There is no exception and the last MEDINFO showed that nurses are making more contributions than ever! How do we have got here? What was our way to reach this level of maturity? What we have done to build a much better future?

Nurse leaders were energized by a variety of motivations. Nurses also always have been in the business of processing information, even before computers were introduced into healthcare industry and become an integral part of the nursing profession.

Florence Nightingale, considered the first health scientist who started documenting and collecting data for statistical analysis proved that the modern nursing practice is an information dependable profession. Nurses depend on accurate and timely access to appropriate information in order to perform the variety of activities that involve patient care, administration, consulting, education and training.

The term, Nursing Informatics was coined by Scholes and Barber in 1980. Maureen Scholes was a pioneer and a very enthusiastic in the field. She participated at the first MEDINFO in 1974 presenting a paper. Years later she was the chair of the First International Conference on
Nursing Informatics that was held in London, England in $1982^{(5)}$.

Following the International Conference on Nursing Informatics, during MEDINFO 1983 (Amsterdam), Elly Plyuter Wenting organized a full oneday seminar. In that seminar, 200 nurses participated, showing the growing interested and raising nurses involvement on the filed. Also, on that seminar, 13 countries were represented: Canada, Denmark, Finland, Germany, Italy, Norway, Saudi Arabia, Scotland, Sweden, Switzerland, The Netherlands, England and United States. This participation demonstrates that nurses in 13 different countries in Europe and North America were developing resources using computers and technology to improve nursing care and education ${ }^{(6)}$.

Additionally, this seminar led to noteworthy fact: - the IMIA Working Group 8 - Nursing Informatics was established. The group was created to serve as an international focus for activities in nursing informatics. The objectives of the group are to promote and teach informatics to nurses and others interested in NI in IMIA country members around the world. It is also provides support to nurses in countries where technology and nursing informatics is emerging.

The first Chair of IMIA WG8 was Maureen Scholes, the vice- chair was Kathryn Hannah (Canada) and Elly Plyuter Wenting (The Netherlands) was appointed as secretary. Currently the group is named IMIA NI SIG (IMIA Nursing Informatics Special Interest and the board of directors are Heather Strachan (England, chair), Robyn Carr (New Zealand, vice-chair, Heimar F. Marin (Brazil, secretary).

As MEDINFO conferences were being organized every three years, the nurse leaders of IMIA NIS SIG also decided that they had enough material to participate at the MEDINFO conferences and also to organize the nursing informatics conferences every three years. Therefore, the conference starts to be organized every three years. Consequently, the second IMIA NI SIG conference was held in Calgary, Canadá, in 1985(7). The third conference was held in Dublin, Ireland ${ }^{(8)}$ in 1988 followed by the Melbourne, Australia Conference (NI'91) ${ }^{(9)}$.

Three years later, in 1994, the conference was held in the city of San Antonio, Texas, United States ${ }^{(10)}$. In 1997 Stockholm (Sweden) was the host city ${ }^{(11)}$ and at the beginning of the twenty first century, the IMIA NI SIG conference was held in Auckland, New Zealand ${ }^{(12)}$. It was the perfect city to welcome the first conference of this century. The conference showed how computer technology became part of every day professional activities and computers could be found in all areas where nurses function. The resources are more beyond comprehension and the limit is just the imagination.

In 2003, from Auckland, the conference moved to Rio de Janeiro, Brazil. This was the first time that the conference was held in a South American country ${ }^{(13)}$. Previously, the conference was located in European, Asian, Australian and North American countries. Moving to a South American country was an advance to the role of the organization.

The Rio de Janeiro conference was a turning point on the tradition of IMIA NI SIG because an outstanding participation of physicians and engineer presenter as primary authors. Two thirds of the participants from 32 countries were nurses. The main topics were education, technology at the point of care, patient safety, wireless, open source, nursing documentation, evidence based for practice and terminology. In some way it was difficult to make a distinction between NI 2003 and MEDINFO. It can be said that that by now we do have MEDINFO and IMIA NI as similar conferences either on the quality of presentations or professional participation. The difference is that IMIA NI conferences deal with health care informatics under nursing leadership, under the nursing point of view. Consequently, it is very pointed out the patient care and patient/professional relationship. At that conference nurses raised their voices; there were not nurses talking to nurses any longer they showed how important contributions nursing informatics does to 


\begin{tabular}{|l|l|}
\hline Degree & Countries \\
\hline Undergraduate & Australia, Brazil, England, Finland, The Netherlands, Norway, Slovenia, Korea, Sweden, USA \\
\hline Specialization (certificate) & Australia, Brazil, Finland, Germany, Norway, Korea \\
\hline Master & Australia, Belgium, Brazil, Finland, Germany, Norway, Korea, Sweden, USA \\
\hline Doctoral & Australia, Brazil, Finland, Germany, Korea, Sweden, USA \\
\hline
\end{tabular}

Table 1: IMIA NI SIG countries that included nursing informatics in nursing curriculum.

improve healthcare to the world population.

The next IMIS NI SIG conference will be held in 2006 in Seoul, Korea (www.ni2006.org). These IMIA NI SIG conferences are currently so mature that can be integrated without loose their identity. It has reached a development level that allows sharing, driving and designing the future of technology application in the field. In addition, we realize that any kind of technological resources, including wireless technology tools are friendly and compatible with nursing care applications. On the other hand, we have to admit that patients are not just patients anymore - we are partners in the health process.

When the group was founded, we had 13 initial countries. Now, we have currently 28 National country members, 3 Institutional members, 21 honorary members. It also includes nine Working Groups: (1) consumer/client health informatics; (2) education; (3) evidence based practice; (4) history; (5) management; (6) nursing concept representation; (7) telematics; (8) open source and standards; (9) standards.

Most of our national members are involved with academic field where they develop educational programs and work to incorporate $\mathrm{NI}$ in the nursing curriculum to prepare the future generations in nursing. However, it is amazing to see that above and beyond the country, the cultural difference and the economic situation of each IMIA NI SIG representative country member, most of members took the same avenue: they had to find out the resources by themselves to incorporate computer and technology in the profession.

Since the beginning IMIA NI leaders are concentrating efforts in education in each country member. Education is a continuous process, a life-long program that never ends. It is recognized that in the globalization times, we need to teach how to find the right information and use the right information to enhance nursing care and promote patient/providers relationship.

Moreover, many countries introduced contents of $\mathrm{NI}$ in the nursing curriculum. From IMIA NI SIG members we learnt that nursing informatics is being taught in several countries, as presented in the Table 1.

The specialty is recognized in the following countries: United States (1992), The Netherlands (1994); Finland (1998), Brazil (1999) and Israel (2004).

It is observed that besides the formal recognition is not in place in several other countries, Nursing Informatics is "de facto" a specialty. No one can oppose to that and the IMIA NI SIG and MEDINFO conference confirm this assumption. Nurses incorporated technology the best way they could in teaching programs, in management and nursing practice.

The specialty does exist and must be recognized by countries associations as it is by IMIA NI SIG, thanks to the efforts of Dr. Virginia Saba, Diane Skiba and Margareta Ehnrfors. The 28 IMIA NI SIG members are pioneers in their own country, are very energetic professionals and they work really hard to enhance the field.

Education programs are being implemented every year, congresses and conferences in Nursing Informatics around the world are getting bigger; development and industry are much more aware about nursing needs today. The integration between academia and industry is much more concrete and several examples in nursing informatics can be found in the literature.

Nursing informatics is not just about the use of computers in nursing care. Technological tools represent one aspect to be considered; however, the science is the foundation of this investment. Nurses must continue to ensure that computer technology remains an integral part of professional practice and that computer is just a mere instrument. The information we share, we record and we analyze is the main aspect of nursing informatics and it will support the evaluation of our contribution to the healthcare services. It also allows us to develop new models that could better utilize resources to improve quality of care and professional performance.

Looking to the scientific publications in the field, it can be realized that the growing and the theme of publications can easily be presented by decades.

\section{The 1960's}

From 1965 to 1969, 47 papers were found. North American nurses that were pioneer in the field led those publications. During this decade, the development of computer systems was driven by financial and administrative factors. Nurses became involved with systems and applications such as staff and billing, schedule, cost and payrolls. Professionals felt the introduction as a threat, a menace that could replace them. The involvement and adoption were very reserved.

\section{The 1970's}

The 1970's decade publications were towards attitude of users. Education and training programs were also being introduced, showing a great concern about to prepare the future generations to use a new instrument to deliver care. In addition, nurses were also exploring how computers could support documentation. The number of specific publication found was a total of 221.Considering the number on the previous decade it can be infer that nurses were working like they only have the present day. So that, they begun to work hard to implement resources to achieve better outcomes. Menace turned into eager to use. There was no place for fear because curiosity was stronger. Professionals were enthusiastic working together to figure out the best way to integrate the new resource into the practice.

\section{The 1980's}

The 80 's were an impressive decade related to the number of publication in nursing informatics. An increase of $450 \%$ in the amount of publication was found. Many countries and many professionals were eager to find out means of how technology and computers could improve nursing performance. More professionals shared their experiences and knowledge. At this decade was created the first dedicated journal in nursing informatics in The United States - Computers in Nursing - which is today named as CIN - Computer, Informatics, Nursing. This decade was also important because IMIA NI SIG was established; the first international conference took place and the term Nursing Informatics was being used to define the field and specialty. We had good instruments 
and we knew how to use our good heart and brain to solve our problems and construct a real good future.

\section{The 1990's}

The nineties testified a great advance of Nursing Informatics. The main focus was the use of computer at bedside. Teaching and learning were also included and the use of Internet was definitively being explored. Health Informatics had no more borders; systems were providing better resources to reach people, to get updated information and to create conditions to promote a dignified life for all.

\section{The 2000's}

The first five years of this century show that many publications are being done in European, Asian and South America countries. The previous decades were led by USA publication but now there is a balance. Expressive contributions are being provided from countries such France, Canada, Japan, Denmark, Korea, Sweden, South Africa, Netherlands Thailand, Brazil and Nigeria. The main themes are related to nursing terminology and nursing minimum data set. Practice and education strategies are also an evident interest of researching.

\section{FINAL CONSIDERATIONS}

To this point and after seeing the evolution of Nursing Informatics through MEDINFO and IMIA NI conferences, I consider nurses in this field, the real winners. We are the largest group of health care providers and we have 6.38 billions of potential patients in the earth, including us. We have to be the best - no choice at all! Our voice is stronger and our skills are strategic in the quality of patient care.

We need to remember that winners do more than enough! That is what our leaders did, that what our colleagues are doing, that is what we must do forever. And because we realized how important is to give our best to reach good scores, we know that besides the level of development, persistent challenges are presented.

These challenges keep our energy and efforts alive. I do hope we face challenges and opportunities forever - facing challenges is part of living activities. While we have those challenges to inspire our personal and profession lives, we are alive! Our profession is alive!!

\section{REFERENCES}

1. Anderson J, Forsythe JM. Editors. Medinfo 1974. Proceedings of the First Congress on Medical Informatics Stockholm (SW): NorthHolland; 1974

2. Lun KC, Degoulet P, Piemme TE, Rienhoff O. Editors. Medinfo 1992. Proceedings of the Seventy Congress on Medical Informatics. Geneva, (SZ): North-Holland; 1992.

3. Greenes R.A, Peterson HE, Protti, DJ (eds). Medinfo '95. Proceedings of the Eight World Congress on Medical Informatics, Vancouver, (CA): North-Holland, 1995

4. Cesnik B, MacGray AT, Scherrer J-R. Editors. Medinfo 1998 Proceedings of the Ninth World Congress on Medical Informatics, Seoul (KO): IOS Press; 1998.

5. Scholes M, Bryant $Y$, Barber B. Editors. The impact of computers in nursing: an international review. Proceeding sof the IFIP-IMIA Workshop on the Impact of computers in nursing, 1982. Amsterdan (NE): North-Holland; 1983.

6. Scholes M, Tallberg M, Pluyter-Wenting E. International Nursing Informatics: a History of the first forty uears $-1960-2000$. Great Britain: British Computer Society; 2000.

7. Hannah KJ, Guillemin EJ, Conklin DN. Editors. Nursing use of computers and information science. Proceedings of the IFIP-MIA

International Symposium. Calgary (CA): North-Holland; 1985.

8. Daly N, Hannah KJ. Editors. Proceedings of the Third Symposium on Nursing Use of computers and information science. Dublin (IR): Mosby Co.; 1988.

9. Hovenga EJS, Hannah KJ, McCormick KA, Ronald JS. Editors. Proceedings of the Fourth International Conference in Nursing Informatics. Use of Computers and Information Science. Melbourne (AUST): Springer-Verlag; 1991.

10. Grobe SJ, Pluyter-Wenting ESP. Editors. Nursing Informatics: an international overview for nursing in a technological era. Proceedings of the Fifth International Conference on Nursing Use of Computers and information science. Austin (USA): Elsevier; 1994.

11. Gerdin U, Tallberg M, Wainwright P. Editors Nursing Informatics'97. Proceedings of the Sixth International Conference on Nursing Informatics. Stockholm (SW): IOS Press; 1997.

12. Carr R, Rocha P. Editors. Nursing Informatics'2000. Proceedings of the Seventh International Conference on Nursing Informatics. Auckland (NZ): New Zealand; 2000.

13. Marin HF, Marques EP, Hovenga E, Goossen W. editors. Nursing Informatics 2003. Proceedings of the Eight International conference in Nursing informatics. Rio de Janeiro (BR): e-Papers; 2003.

Data do recebimento: $18 / 07 / 2005$

Data da aprovação: $\quad$ 20/06/2005

\section{Acknowledgments:}

Special thanks to Dr. Mario Stefanelli and Dr. Casimir Kullkowski (SPC Chairs) and Dr. Edward Shortliffe (OC Chair) for inviting me as keynote presenter at MEDINFO 2005.

This work was also partially funded by grant 1\#1 D43 TW7015-01 for Informatics for Global Health; Fogarty International Center, NLM, NIBIB, NIH and by CNPq 300460/2003-1. 